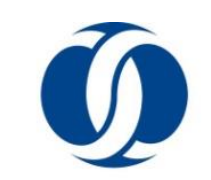

European Bank

for Reconstruction and Development

\title{
The inner workings of the board: evidence from emerging markets
}

\author{
Ralph De Haas, Daniel Ferreira and Tom Kirchmaier
}

\begin{abstract}
We survey non-executive directors in emerging markets to obtain detailed information about the inner workings of corporate boards across a variety of institutional settings. We document substantial variation in the structure and conduct of boards as well as in directors' perceptions about the local legal environment. Further analysis indicates that directors who feel adequately empowered by local legislation are less likely to actively vote against board proposals. They also form boards that play a stronger role in the company's strategic decision-making. This suggests that a supportive legal environment allows directors to focus more on their advisory, as opposed to their monitoring, role.
\end{abstract}

Keywords: Boards of directors, corporate governance, emerging markets

JEL Classification Number: G30, G38, K22

Contact details: Ralph De Haas, One Exchange Square, London EC2A 2JN, UK. Phone: +4420 7338 7213; email: dehaasr@ebrd.com.

Daniel Ferreira, London School of Economics, Department of Finance, Houghton Street, London WC2A 2AE, UK. Phone: +44 207955 7544; email: d.ferreira@Ise.ac.uk.

Tom Kirchmaier, London School of Economics, Financial Markets Group, Houghton Street, London WC2A 2AE, UK. Phone: +44 207955 6854; email: t.kirchmaier@Ise.ac.uk

Ralph De Haas is the Director of Research at the EBRD. Daniel Ferreira is a Professor of Finance at the Department of Finance at the London School of Economics. Tom Kirchmaier is a Researcher at the Financial Markets Group of the London School of Economics.

This project was conceived and promoted with the invaluable help of Erik Berglöf and Franklin Steves. The authors would like to thank Renée Adams, Gian Piero Cigna, Carsten Gerner-Beuerle, Sergei Guriev and Nikola Milushev for helpful comments, all board directors that participated in the study for their time, and Oana Furtuna, Adeline Pelletier and Carly Petracco for excellent research assistance.

The working paper series has been produced to stimulate debate on economic transition and development. Views presented are those of the authors and not necessarily of the EBRD. 


\section{Introduction}

The board of directors forms an integral part of a firm's governance mechanisms. Board members are appointed by shareholders to promote their interests and to supervise and advise the chief executive and other executives. How boards perform this dual role of supervisor and adviser of corporate management is typically difficult to observe from outside the company, and board conduct therefore remains an underexplored topic in the literature. This holds even more so for boards in developing countries and emerging markets, where transparency and reporting requirements tend to be less advanced.

To gain a better understanding of the inner workings of the board, this paper exploits data collected through an online survey to which 130 current and past board directors responded. These non-executive directors were on the boards of companies across 27 emerging markets, ranging from Poland in eastern Europe to Mongolia in Asia. We use these board nominees as entry points to access detailed information about the behaviour and conduct of their boards. The survey elicits information on the board's priorities, the relationships between boards and management, the legal environment in which board members operate, board procedures and the role of independent (non-executive) directors.

Our sample comes from the set of directors appointed by the European Bank for Reconstruction and Development (EBRD) to board seats in companies in which the EBRD is an investor. In addition to providing firms with debt funding, the EBRD also invests in a broad range of industries. These equity investments are usually held for a period of between four and seven years. During this period an independent director representing the EBRD typically joins the investee company's Board of Directors. Because all directors in our sample are professional nominees of a single minority investor, we can safely assume that such directors understand the need to look after the interests of non-controlling investors, which is a group that might include creditors.

Our primary contribution is to describe the inner workings of the board from the perspective of (truly) outside directors. Our analysis is mainly descriptive; sample size and data limitations make detailed statistical or causal inferences impossible. We use the survey as a tool to measure different aspects of board activity and to describe the heterogeneity in board characteristics across regions in our sample. We document substantial variation in the 
structure and conduct of boards, as well as in directors' perceptions about the local legal environment.

Our data allow us to create measures of advising and monitoring activity inside boards. Board advice is usually understood as active participation in decisions of a strategic nature (see, for example, Adams and Ferreira, 2007). Perhaps surprisingly, we find that the board makes the final decision on strategic issues in more than 50 per cent of cases. This evidence shows that boards are often empowered in their advisory functions. We also measure a director's monitoring intensity by the frequency with which they vote against board proposals. We find that 69 per cent of directors have voted against board proposals at least once during their tenure. We conclude that our sample directors appear to be significantly engaged in both advising and monitoring activities.

We also use our survey to create measures of board quality and meeting quality. Our board quality index is based on five measures of best practices and competence. We find that board quality is highest in Central Asian and eastern European countries, and lowest in Russia. Our measure of meeting quality can be decomposed into meeting intensity (number of meetings, length of meetings and attendance) and information quality. We find that the number of meetings and hours spent in meetings increased between 2007 and 2009, but the quality of information provided to participants deteriorated. This suggests that board activity becomes intensified in periods of crisis, but information quality does not improve.

Lastly, our data allow some interesting comparisons across regions. As the largest country in our sample, Russia stands out with the lowest level of board participation in strategic decisions. In addition, outside directors in Russia vote against board proposals very frequently. The combined evidence suggests that directors representing minority investors face significant challenges in Russia: the board is not sufficiently empowered to engage in strategic decision-making, while controlling parties' interests often conflict with those of non-controlling investors.

This paper provides three main contributions to the board literature. First, we provide new evidence that outside directors are active participants in the decision-making process inside the firm. There is a debate in the theoretical literature on boards about the relative importance 
of advising and monitoring activities inside the board. ${ }^{1}$ But there is scant empirical evidence on this issue. An exception is the paper by Schwartz-Ziv and Weisbach (2013), who analyse minutes of board meetings of 11 Israeli (and partially state-owned) companies. They conclude that boards spend significantly more time on monitoring activities than on advisory activities. And they also find little evidence of directors voting against management. By contrast, we find that the board has the final say on strategic issues in about half of the sample, and that a substantial majority of outside directors vote against firm proposals. In short, we find no evidence of board complacency and director inaction.

Second, we add to the scarce literature on corporate boards in emerging markets. Although corporate boards play an increasingly important role in many emerging markets, we know little about how effective they are and to what extent their functioning depends on external factors. Klapper and Love (2004) use data from 14 developing countries to show that firmlevel corporate governance matters more in countries with weak legal environments and that firms may partially compensate for ineffective laws by establishing good corporate governance. This insight is confirmed by Dahya, Dimitrov and McConnell (2008) who analyse 799 firms (all with a dominant shareholder) in 22 countries. They find a positive relationship between corporate value and the proportion of independent board directors. Especially in countries with weak legal shareholder protection, dominant shareholders can appoint an independent board to assure minority investors that they will refrain from diverting resources. Ferreira, Kirchmaier and Metzger (2010) use a sample of the world's largest banks to document that board independence is mostly driven by country-specific laws and regulations. Likewise, Black and Kim (2012) show how a legal change in Korea led to increased board independence and higher firm valuations. Our contribution here is, first, to paint a more granular picture of board conduct and, second, to correlate directors' perceptions of their legal environment with several key aspects of board conduct. We show that a supportive legal environment allows directors to focus more on their advisory, as opposed to their monitoring, role.

Third, much of the literature on corporate boards relies on publicly available information such as annual reports. These contributions typically relate (changes in) observable board

\footnotetext{
${ }^{1}$ See, for instance, Hermalin and Weisbach (1998), Song and Thakor (2006), Adams and Ferreira (2007) and Harris and Raviv (2008). For a survey of this literature, see Adams, Hermalin and Weisbach (2010).
} 
structures to outcomes such as CEO turnover and firm performance. For instance, Nguyen and Meisner Nielsen (2010) find that sudden deaths of US directors result in significant stock-price declines, especially in the case of independent directors. Instead, this paper contributes to a nascent finance literature that uses surveys and structured interviews to collect information on inherently opaque topics. Examples include Leblanc and Gillies (2005), who interview directors of North American companies to distinguish between "functional" and "dysfunctional" boards; Campello, Graham and Harvey (2010), who interview CFOs to develop survey-based measures of credit constraints; Graham, Harvey and Puri (2015), who use CEO and CFO interviews to study the delegation of financial decisions within firms; and Beck, Degryse, De Haas and Van Horen (2017), who conduct interviews with bank CEOs to learn about bank lending techniques.

The remainder of this paper is structured as follows. Section 2 describes our director survey and the related sample, after which section 3 documents the main patterns in our data. Section 4 focuses on the relationship between the legal empowerment of directors and the role of boards in strategic decision-making. Section 5 concludes. 


\section{The survey and sample}

The surveys to collect the information analysed in this paper were conducted through a secure online survey platform in early 2012. Each of the board members who were invited to participate had been nominated by the EBRD, an international financial institution that holds equity stakes in private companies across a variety of emerging markets. The aim of the survey was to collect information about how board members in these countries perceive their own role, that of their board, as well as the local legal and institutional environment they operate in. Annex 1 to this paper contains the full survey instrument.

\section{Chart 1}

Geographical distribution of the sample of surveyed board directors

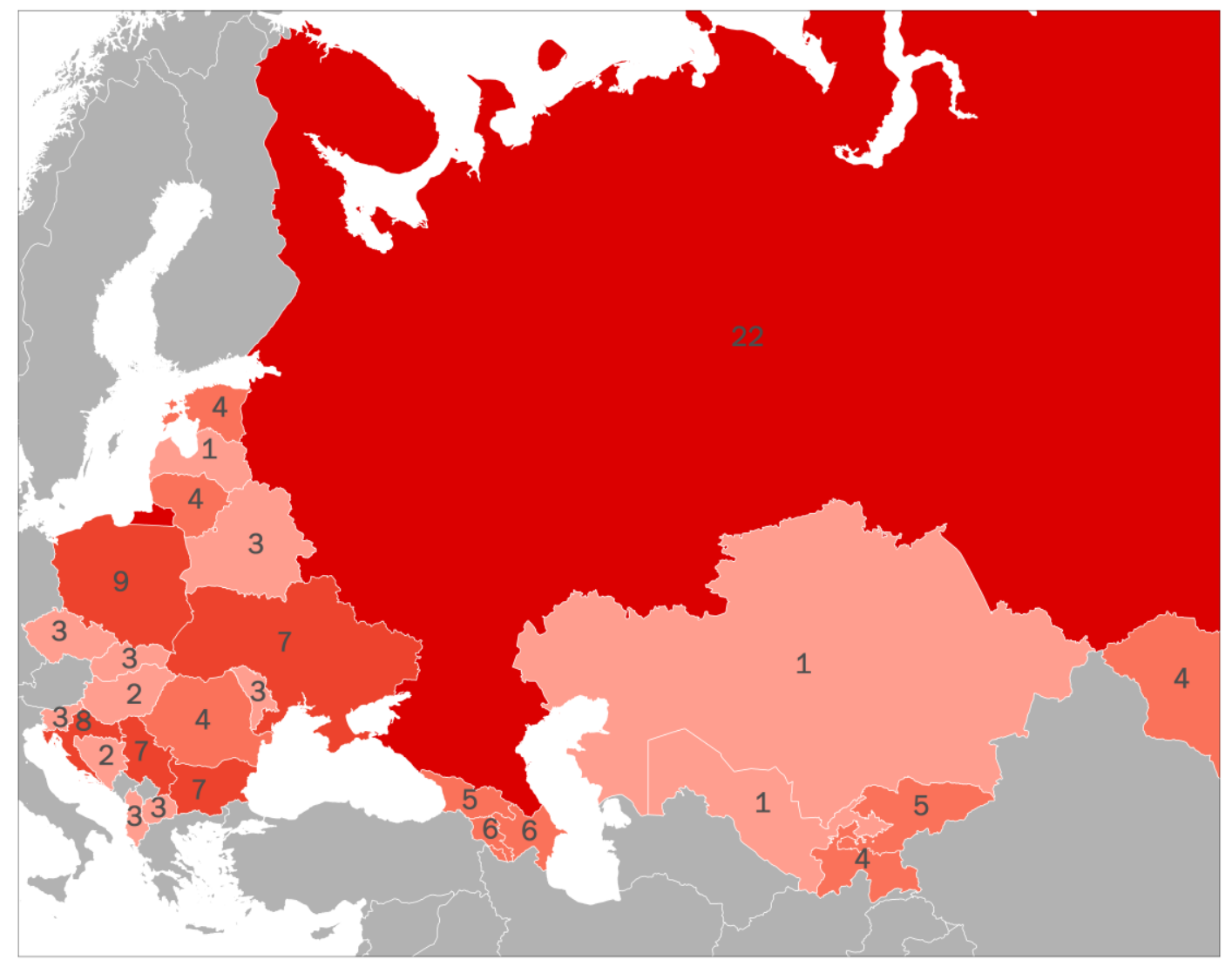

Note: This map shows the number of respondents (board directors) by country. Darker colours indicate a higher number of observations per country.

A total of 246 surveys were sent to all current and past EBRD board nominees and 130 responses were returned, giving us a response rate of 53 per cent. These 130 board directors supervised and advised companies in 27 different countries (Chart 1). 
Table 1

Summary statistics

\begin{tabular}{|c|c|c|c|c|c|}
\hline & Mean & $S d$ & Min & $\operatorname{Max}$ & $N$ \\
\hline \multicolumn{6}{|l|}{ Director characteristics } \\
\hline Male (dummy) & 0.75 & 0.43 & 0 & 1 & 130 \\
\hline Western (dummy) & 0.62 & 0.49 & 0 & 1 & 130 \\
\hline Board experience (dummy) & 0.52 & 0.50 & 0 & 1 & 130 \\
\hline Industry experience (dummy) & 0.45 & 0.50 & 0 & 1 & 130 \\
\hline \multicolumn{6}{|l|}{ Company characteristics } \\
\hline Finance sector (dummy) & 0.45 & 0.50 & 0 & 1 & 130 \\
\hline Two-tier board (dummy) & 0.70 & 0.46 & 0 & 1 & 130 \\
\hline Board size & 6.51 & 2.94 & 2 & 17 & 85 \\
\hline Female participation & 0.10 & 0.12 & 0 & 0.57 & 83 \\
\hline Minority independent board members (dummy) & 0.72 & 0.45 & 0 & 1 & 120 \\
\hline NED share & 0.65 & 0.29 & 0 & 1 & 84 \\
\hline \multicolumn{6}{|l|}{ Board conduct } \\
\hline Board duties (days per month) & 2.67 & 1.67 & 1 & 10 & 130 \\
\hline Board sets clear targets (dummy) & 0.81 & 0.40 & 0 & 1 & 125 \\
\hline Board follows up on targets (dummy) & 0.77 & 0.42 & 0 & 1 & 124 \\
\hline Meets without management (dummy) & 0.29 & 0.45 & 0 & 1 & 125 \\
\hline Strategy-away days (dummy) & 0.20 & 0.40 & 0 & 1 & 126 \\
\hline Knowledge of management (1: very bad; 6 : very good) & 4.80 & 0.91 & 2 & 6 & 127 \\
\hline Competence \& qualification of board & 0.66 & 0.48 & 0 & 1 & 121 \\
\hline Board quality index & 0.53 & 0.27 & 0 & 1 & 130 \\
\hline \multicolumn{6}{|l|}{ Meeting characteristics } \\
\hline Meeting quality index & 0.41 & 0.10 & 0 & 1 & 102 \\
\hline Meeting intensity index & 0.39 & 0.16 & 0 & 1 & 99 \\
\hline Meeting information index & 0.43 & 0.14 & 0 & 1 & 102 \\
\hline Number of board meetings & 5.40 & 2.99 & 0 & 15 & 89 \\
\hline Duration board meeting & 4.69 & 3.46 & 0 & 24 & 89 \\
\hline Percentage by phone & 17.96 & 28.29 & 0 & 100 & 52 \\
\hline Sufficient information (dummy) & 0.66 & 0.48 & 0 & 1 & 92 \\
\hline Days before board papers received & 5.15 & 3.35 & 0 & 15 & 89 \\
\hline \multicolumn{6}{|l|}{ Power distribution within the board } \\
\hline Chairperson sets board agenda (dummy) & 0.40 & 0.49 & 0 & 1 & 126 \\
\hline Final decision with board & 0.52 & 0.50 & 0 & 1 & 128 \\
\hline Votes against (1: never; 4: often) & 1.99 & 0.80 & 1 & 4 & 122 \\
\hline Never votes against & 0.31 & 0.47 & 0 & 1 & 122 \\
\hline \multicolumn{6}{|l|}{ Board director views on judicial fairness and empowerment } \\
\hline Court quality (dummy) & 0.50 & 0.50 & 0 & 1 & 116 \\
\hline Legislation empowers (1: strongly disagree; 6 : strongly agree) & 4.61 & 0.82 & 1 & 6 & 127 \\
\hline No role government nominating new directors (dummy) & 0.82 & 0.38 & 0 & 1 & 124 \\
\hline
\end{tabular}

Source: EBRD Board Director Survey.

Note: This table presents summary statistics for all variables used in the paper. Appendix Table A1 contains the variable definitions. NED=Non-executive director. 
The observations are relatively equally distributed over five geographic regions: central and eastern Europe and the Baltic states (25 companies); south-eastern Europe (30 companies); eastern Europe and the Caucasus (38 companies), Russia (22 companies), and Central Asia (15 companies). ${ }^{2}$ Table 1 provides summary statistics for selected variables and Table A1 in Annex 2 provides all variable definitions.

The first panel of Table 1 shows that three out of four board directors in our sample are male and that just over 60 per cent are from western Europe or North America. ${ }^{3}$ The rest holds the nationality of the country of incorporation. Slightly over half of the respondents have prior experience as a board member, with the percentage of experienced board members ranging from 60 per cent in eastern Europe and the Caucasus to only 40 per cent in Central Asia. Less than half of all directors have prior experience in the industry where they currently hold a board membership. The percentage of experienced board members ranges from 33 per cent in eastern Europe and the Caucasus to 64 per cent in south-eastern Europe.

The second panel of Table 1 shows that 45 per cent of all companies where we surveyed directors are in the financial sector - mainly banks and insurance companies. Another 10 per cent of the companies are in the retail, manufacturing, energy and mining sectors. In 70 per cent of the companies there is a two-tier board, in which the executive directors are part of an executive board while all non-executive directors make up a separate supervisory board (in Russia only half of all surveyed companies have a two-tier board). The remaining 30 per cent of companies have a one-tier board composed of both executive and non-executive directors.

The boards in our sample comprise on average almost 6.5 members but variation is large with board size ranging between 2 and 17 members. Average board size is quite similar across the five regions, with Russian boards typically being the largest (7.3 directors on average). ${ }^{4}$ On a

${ }^{2}$ Central Europe and the Baltic States (Croatia, Czech Republic, Estonia, Hungary, Latvia, Lithuania, Poland, Slovak Republic and Slovenia); south-eastern Europe (Albania, Bosnia and Herzegovina, Bulgaria, FYR Macedonia, Romania and Serbia); eastern Europe and the Caucasus (Armenia, Azerbaijan, Belarus, Georgia, Moldova and Ukraine); Russia; and Central Asia (Kazakhstan, Kyrgyz Republic, Mongolia, Tajikistan and Uzbekistan).

${ }^{3}$ Giannetti, Liao and Yu (2015) show that when Chinese companies hire directors with foreign experience, this improves firm productivity and valuation.

${ }^{4}$ The empirical evidence suggests that larger boards are often associated with weaker firm performance (Yermack, 1996; and Eisenberg, Sundgren and Wells, 1998). 
typical board, only 10 per cent is female and on average two-thirds are non-executive directors (NEDs). NEDs are least common in Russia (54 per cent on average). According to the Institute of International Finance (IIF, 2002) at least one third of the board should be nonexecutive, a majority of whom should be independent. In our dataset, 11 per cent of all boards do not comply with that minimum requirement. ${ }^{5}$

${ }^{5}$ Tougher boards - those with more NEDs and more independent NEDs - are associated with relatively intense monitoring and more performance-induced CEO turnover. However, such high turnover may destroy value if CEOs are fired too often for reasons outside their control (Jenter and Kanaan, 2015). 


\section{Inside the board: some facts}

\subsection{Board conduct and quality}

How do boards operate in practice? The survey indicates that directors spend an average of 2.7 days a month on their board duties, but there is quite a bit of variation, with some board members spending just one day a month on their duties whereas others spend up to 10 days a month (Table 1).

More than 80 per cent of the board directors think their boards set clear targets, and a similar percentage indicate that, in general, the board follows up on the targets that are set. Of all boards, 29 per cent have a meeting at least once a year for all non-executive directors without management present, and 20 per cent of boards hold independent "strategy away days". These numbers are considerably lower in Russia (19 and 5 per cent, respectively), suggesting a less independent role for boards in this country. Moreover, 35 per cent of the surveyed directors felt that the board did not have a good understanding of the second level of management. This finding holds consistently across regions.

Taken together, these results suggest that interactions between the board and senior management vary significantly across countries and companies. To analyse this variation in more detail, we create an index of board quality which is based on measures of best practices and competence, by averaging across five (normalised) variables: Strategy away days; Meets without management; Board sets clear targets; Board follows up on targets; and Competence and qualification of board. The first four are indicator variables, as defined in Table A1, while the fifth is based on the question "How would you judge the competence and qualification level of the Board as a whole?". Respondents report that the board was "very qualified" in 67 per cent of the cases, "somewhat qualified" in 27 per cent of the cases, and "unqualified or incompetent" in 6 per cent of the cases. For our index, we construct an indicator variable that equals one if the board is very qualified and zero otherwise.

Table 2 reports the averages of the board quality index across the five regions. We find that board quality is highest in eastern Europe and the Caucasus as well as Central Asia, and lowest in Russia. 
Table 2

Board quality index

\begin{tabular}{|c|c|c|c|}
\hline & \multicolumn{3}{|c|}{ Board quality index } \\
\hline & (1) & (2) & (3) \\
\hline Region & Mean & $S d$ & Freq. \\
\hline Central Asia & 0.59 & 0.31 & 15 \\
\hline Central Europe and the Baltic states & 0.51 & 0.27 & 38 \\
\hline Eastern Europe and the Caucasus & 0.59 & 0.23 & 30 \\
\hline Russia & 0.49 & 0.27 & 22 \\
\hline South-eastern Europe & 0.50 & 0.30 & 25 \\
\hline Total & 0.53 & 0.27 & 130 \\
\hline
\end{tabular}

Source: EBRD Board Director Survey.

Note: This table presents summary statistics, by region, for the variable Board quality index. This index is an unweighted average of the following five normalised variables: Strategy away days; Meets without management; Board sets clear targets; Board follows up on target; Competence and qualification of board. All variables are dummies based on 'yes' or 'no' answers except for Competence and qualification of board which is ' 1 ' when the board is regarded as (very) qualified and ' 0 ' otherwise.

\subsection{Board meetings}

Boards convene around five times a year and the average board meeting lasts five hours. According to the IIF (2002), boards of large companies should convene at least once every quarter. While the average company in our sample meets that target, in 2009 about 7 per cent of firms did not meet the target of meeting at least twice a year. Moreover, 18 per cent of the directors on the boards we analyse typically participate in board meetings by telephone.

Directors receive their papers in preparation for the meeting on average five days in advance, although practice varies a lot, with some companies distributing the relevant materials two weeks in advance whereas in other cases materials are only handed out on the day of the board meeting itself. According to the IIF (2002), the best practice is to send a notice of the meeting and the agenda at least one month prior to the meeting. About two-thirds of all directors indicate that they think that they receive sufficient information to fulfil their duties. Worryingly, this means that a third of surveyed directors feel insufficiently informed to be able to properly fulfil their tasks.

We create a summary measure of meeting quality by averaging across five (normalised) variables: Number of board meetings (per year); Duration of board meetings; percentage of participants by telephone (Percentage by phone), Sufficient information; and Days before 
board papers received. Table 3 reports the averages of this meeting quality index across the five regions. We find no significant differences in meeting quality across regions.

We then further decompose the meeting quality index into two distinct sub-indices: Meeting intensity (number of meetings, length of meetings, and attendance); and Information quality (meeting information and days before meeting that papers are received). Perhaps surprisingly, we find that Russia has the highest level of meeting information quality, although it has the lowest level of meeting intensity.

Table 3

Number and quality of board meetings

\begin{tabular}{|c|c|c|c|c|c|c|c|c|c|}
\hline \multicolumn{10}{|c|}{ Panel A: Meeting quality, meeting intensity and information quality } \\
\hline & $(1)$ & (2) & (3) & $(4)$ & $(5)$ & (6) & $(7)$ & $(8)$ & $(9)$ \\
\hline & \multicolumn{3}{|c|}{ Meeting quality index } & \multicolumn{3}{|c|}{ Meeting intensity index } & \multicolumn{3}{|c|}{ Meeting information index } \\
\hline & Mean & $S d$ & Freq. & Mean & $S d$ & Freq. & Mean & $S d$ & Freq. \\
\hline Central Asia & 0.40 & 0.11 & 11 & 0.40 & 0.19 & 11 & 0.40 & 0.12 & 11 \\
\hline Central Europe and the Baltic states & 0.43 & 0.09 & 32 & 0.42 & 0.14 & 30 & 0.43 & 0.10 & 32 \\
\hline Eastern Europe and the Caucasus & 0.40 & 0.10 & 23 & 0.36 & 0.15 & 23 & 0.43 & 0.12 & 23 \\
\hline Russia & 0.42 & 0.12 & 19 & 0.35 & 0.14 & 19 & 0.50 & 0.17 & 19 \\
\hline South-eastern Europe & 0.40 & 0.11 & 17 & 0.43 & 0.18 & 16 & 0.37 & 0.18 & 17 \\
\hline Total & 0.41 & 0.10 & 102 & 0.39 & 0.16 & 99 & 0.43 & 0.14 & 102 \\
\hline
\end{tabular}

Panel B: Differences between 2009 and 2007

\begin{tabular}{lccccc}
\cline { 2 - 5 } & $(10)$ & $(11)$ & $(12)$ & $(13)$ & $(14)$ \\
\cline { 2 - 5 } & Obs & Mean & Sd & Min & Max \\
Number of board meetings & 41 & 0.54 & 1.76 & -4 & 6 \\
Duration board meeting & 41 & 0.61 & 2.11 & -3 & 8 \\
Days before board papers received & 41 & 0.00 & 1.96 & -7 & 5 \\
Sufficient information & 41 & -0.17 & 0.74 & -2 & 2 \\
Percentage by telephone & 22 & -0.04 & 11.67 & -0 & 0.12 \\
\hline
\end{tabular}

Source: EBRD Board Director Survey.

Note: Meeting quality index is an unweighted average of the following normalised variables: Number of board meetings (per year); Duration board meeting; Percentage by telephone; and Days before board papers received. Meeting intensity index includes Number of board meetings; Duration board meeting; and Percentage by telephone. Meeting information index includes Sufficient information and Days before board papers received. Panel B shows the differences between the absolute values of various meeting variables between 2009 and 2007.

Table 3 also provides, for each component of the meeting quality index, the difference between the index value in 2009 and 2007. Although we caution against extrapolating from such a small sample, the comparison between 2007 and 2009 is interesting because it may indicate changes in board behaviour in crisis periods. The evidence shows that both the number of meetings and the hours spent on meetings increased between 2007 and 2009. However, the quality of information provided to participants deteriorates over this period. 
These findings suggest that not only do boards become more active during crises, but also that the information provided to board members tends to be of lower quality.

\subsection{Power distribution within the board}

Who, in practice, has the power on companies' boards? The survey indicates that in 40 per cent of companies the board's agenda is set by the chairperson of the board and in 12 per cent it is determined by the non-executive directors. In the remaining 48 per cent of companies the board's agenda is wholly or partially set by management. The role of the chairperson of the board appears strongest in eastern Europe and the Caucasus, where it is the chairperson that sets the board's agenda in 75 per cent of the companies that were analysed.

\subsection{Judicial fairness and the empowerment of board directors}

When board directors were asked whether courts in their country normally ruled fairly and objectively, exactly half of all board directors said they did, whereas the other half said they didn't. However, perceptions of court quality vary a lot across and within regions, ranging from 81 per cent in central Europe and the Baltic states to only 21 per cent in Central Asia. Relatedly, the survey also presented board members with a case study about a hypothetical conflict between shareholders and the board (see Annex 2 for the full case study).

Respondents were asked whether they thought that the courts in their respective countries would rule fairly and objectively in this case. The opinions were again split: around half of all board members said they did not think that this would happen.

When asked whether local legislation gives the director enough power to fulfil their role within the board, the average score is 4.6 on a scale of 1 ("Strongly disagree") to 6 ("Strongly agree"). Variation is again substantial with a standard deviation of 0.82 . While 66 per cent of the directors (strongly) agree that local legislation gives them enough power, the remainder agree only somewhat or even disagree altogether. Legal empowerment is again higher in central Europe and the Baltic states (4.9) and lower in Russia (4.4).

Lastly, the survey results also indicate that in four out of five companies the government plays no role in the nomination of new directors. Yet, in 10 per cent of the companies the government plays a formal role whereas in 6 per cent it plays some kind of informal role. Note that all companies surveyed were privately (that is, not government) owned. 


\section{Decision-making inside the board}

Corporate directors often play a dual role. In their monitoring role, directors are supposed to look after the interests of all shareholders - including non-controlling ones - and, sometimes, of other stakeholders, as stated in the local corporate law. While performing their duty, directors will often find themselves in disagreement with management and controlling shareholders. Such disagreement can lead to concrete actions, such as voting against management and/or controlling shareholders. In their advisory role, directors contribute with their business expertise to the formulation and implementation of a company's strategy. As in the related literature, we define advice as the provision of inputs for strategic decisions, such as mergers and acquisitions, market entry and exit, and so on. For such advice to be meaningful, the board needs to be empowered to make strategic decisions.

In this section, we analyse two subjective measures of decision-making inside the board. Both measures are related to how effectively directors can perform their monitoring and advisory functions. The first measure relates to the board's ability to participate meaningfully in strategic decision-making. The second measure proxies for the frequency of disagreement between directors and the rest of the board.

We first asked directors to identify "who usually makes the final decision on strategic issues". Panel A in Table 4 reports the results. We find that in 52 per cent of all cases the board makes the final decision on strategic issues, while in 41 per cent of companies it is the majority shareholder, and in the remaining 7 per cent it is management. This indicates that in most companies, board directors take an active advisory role and do not limit themselves to merely monitoring management.

The breakdown of answers reveals striking differences between regions. While Central Asian countries show the highest level of board involvement in strategic issues ( 71 per cent), in Russia only 41 per cent of surveyed companies effectively delegate strategic decisions to the board. One possible explanation for these cross-country differences is variation in the perception of the quality of the legal environment. Our data show that there is wide variation in how board directors assess the quality of the local legal system and the extent to which it empowers them to fulfil their role. Indeed, the first bar chart of Chart 2 shows that, when board directors feel more empowered by the local legal system (that is, the ability of local 
laws to empower directors is above the mean), it is much more likely that final decisions are taken by the board (58 per cent) than when directors feel less empowered (39 per cent).

Table 4

Boards and corporate decision making

\begin{tabular}{|c|c|c|c|c|c|c|c|}
\hline \multicolumn{4}{|c|}{ Panel A: Board makes final strategic decisions } & \multicolumn{4}{|c|}{ Panel B: Board member never votes against proposals } \\
\hline \multirow[t]{2}{*}{ Region } & Mean & $S d$ & Freq. & Region & Mean & $S d$ & Freq. \\
\hline & (1) & (2) & (3) & & (4) & (5) & (6) \\
\hline Central Asia & 0.71 & 0.47 & 14 & Central Asia & 0.23 & 0.44 & 13 \\
\hline Central Europe and the Baltic states & 0.51 & 0.51 & 37 & Central Europe and the Baltic states & 0.33 & 0.48 & 36 \\
\hline Eastern Europe and the Caucasus & 0.57 & 0.50 & 30 & Eastern Europe and the Caucasus & 0.31 & 0.47 & 29 \\
\hline Russia & 0.41 & 0.50 & 22 & Russia & 0.24 & 0.44 & 21 \\
\hline South-eastern Europe & 0.44 & 0.51 & 25 & South-eastern Europe & 0.39 & 0.50 & 23 \\
\hline Total & 0.52 & 0.50 & 128 & Total & 0.31 & 0.47 & 122 \\
\hline
\end{tabular}

Source: EBRD Board Director Survey.

Note: This table presents summary statistics, by region, for the variables Final decision with board (Panel A) and Never votes against (Panel B). Final decision with board is a dummy variable that is ' 1 ' if the final decisions on strategic issues are usually taken by the board and ' 0 ' if they are usually taken by management or the majority shareholder. Never votes against is a variable based on the frequency with which the director votes against board proposals (1: never; 4: often). It shows the proportion of board members that never voted against a board proposal.

We further investigate this hypothesis in Table 5. We run OLS regressions to analyse the relationship between legal empowerment and whether the final decision authority for strategic issues lies with the board or, in contrast, with either management or the majority shareholder. The dependent variable is an indicator that equals one if the board makes the final decision on strategic issues.

We explore the role of two legal variables that may determine whether final decisions are taken by the board. Legislation empowers is our variable that measures to what extent directors think that local legislation gives them enough power to adequately fulfil their role within the board (1: "Strongly disagree"; 6: "Strongly agree"). Second, we use a more generic variable (Court quality) which is a dummy that is 1 if the director thinks that the courts would rule fairly and objectively in the case study that was presented to them. In addition, the even columns include fixed effects for the director's home region as well as fixed effects for the country where the company is incorporated. In these columns, we thus compare board directors operating in one and the same country. Throughout the table, we also control for the respondent's Industry experience, gender (Male), whether the board is a Two-tier board and whether the firm is in the Finance sector. 


\section{Chart 2}

\section{Legal empowerment, decision authority of boards and director voting activity}
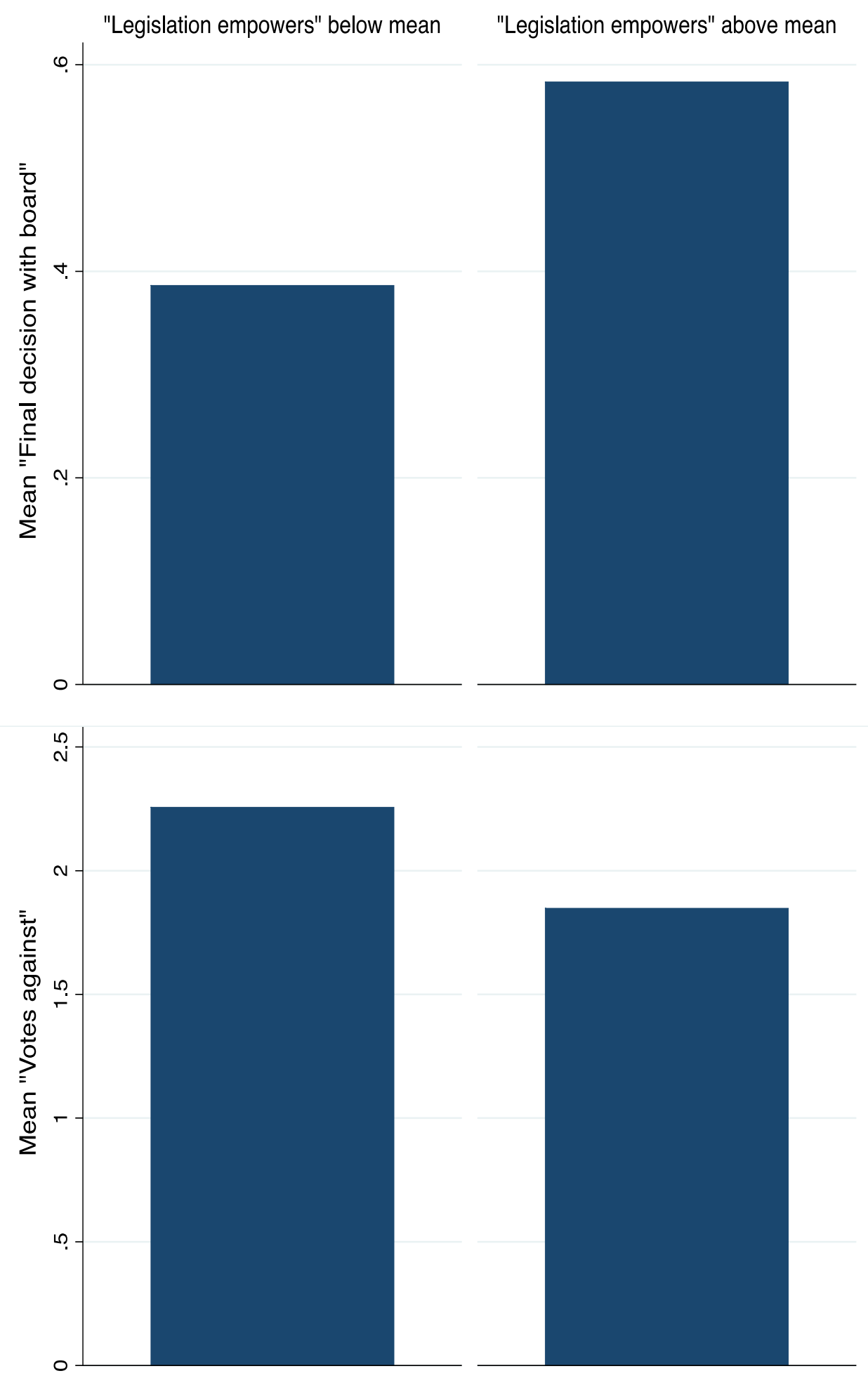

Note: These bar charts show the mean value of the variables Final decision with board (top) and Votes against (bottom) for board directors who answer that they regard themselves as relatively little empowered by local legislation (left bars) and those who feel more empowered by local legislation (right bars). 
The results in Table 5 confirm that if board directors are adequately empowered by local legislation, it is more likely that the boards they comprise play a stronger role in the company's strategic decision-making. Interestingly, there is no such role for the more generic question on court quality (columns 3 and 4). When we add both variables at the same time (columns 5 and 6), we continue to find a strong and significant positive relationship between director empowerment and the role of the board in strategic decisions. These results hold up independently of whether we include country fixed effects.

\section{Table 5}

Legal empowerment of directors and the decision authority of boards

\begin{tabular}{lcccccc}
\hline & \multicolumn{5}{c}{ Final decision with board } \\
\cline { 2 - 7 } & $(1)$ & $(2)$ & $(3)$ & $(4)$ & $(5)$ & $(6)$ \\
\cline { 2 - 7 } Legislation empowers & $0.142^{* * *}$ & $0.120^{* *}$ & & & $0.142^{* * *}$ & $0.108^{*}$ \\
& {$[3.394]$} & {$[2.357]$} & & & {$[2.935]$} & {$[1.844]$} \\
Court quality & & & 0.081 & 0.103 & 0.000 & 0.068 \\
Industry experience & 0.136 & 0.146 & 0.120 & 0.137 & 0.139 & 0.158 \\
& {$[1.579]$} & {$[1.429]$} & {$[1.286]$} & {$[1.178]$} & {$[1.502]$} & {$[1.373]$} \\
Male & $0.246 * *$ & 0.158 & $0.270 * *$ & 0.205 & $0.252^{* *}$ & 0.191 \\
& {$[2.499]$} & {$[1.234]$} & {$[2.505]$} & {$[1.495]$} & {$[2.324]$} & {$[1.395]$} \\
Two-tier board & -0.118 & -0.053 & -0.111 & -0.017 & -0.099 & -0.015 \\
& {$[-1.216]$} & {$[-0.430]$} & {$[-1.041]$} & {$[-0.115]$} & {$[-0.973]$} & {$[-0.102]$} \\
Finance sector & -0.002 & -0.062 & -0.004 & -0.022 & -0.036 & -0.045 \\
& {$[-0.024]$} & {$[-0.552]$} & {$[-0.042]$} & {$[-0.174]$} & {$[-0.347]$} & {$[-0.352]$} \\
Director region fixed effects & No & Yes & No & Yes & No & Yes \\
Country fixed effects & No & Yes & No & Yes & No & Yes \\
Observations & 127 & 127 & 115 & 115 & 115 & 115 \\
R-squared & 0.131 & 0.338 & 0.092 & 0.307 & 0.141 & 0.330 \\
\hline
\end{tabular}

Source: EBRD Board Director Survey.

Note: This table presents linear probability regressions to estimate the relationship between perceived legal empowerment of directors and the probability that the final decision authority on strategic decisions lies with the board. Even columns include fixed effects for the director's home region and country fixed effects. Table A1 contains all variable definitions. Robust t-statistics in brackets. $* * * \mathrm{p}<0.01, * * \mathrm{p}<0.05, * \mathrm{p}<0.1$.

The second measure of decision-making inside the board is the proportion of directors who have ever voted against board proposals. Panel B in Table 4 summarises this variable. Our data show that 69 per cent of directors have voted against board proposals at least once during their tenure. Our sample directors thus appear to be significantly engaged in monitoring activities. There is little variation in monitoring intensity across regions. We find that directors vote somewhat more frequently against proposals in Central Asia (77 per cent) and Russia (76 per cent), and more rarely in south-eastern Europe (61 per cent). 
We expect independent directors to vote against projects that may harm the interest of noncontrolling investors. Thus, a high frequency of voting against projects could be explained by a combination of high levels of director independence and a large number of proposals that are harmful to the interests of non-controlling shareholders. We note, however, that the fact that a substantial minority of directors never votes against board proposals is not necessarily a bad thing, as it is quite possible for disagreements to be discussed and cleared up in the boardroom without a formal vote taking place.

The second bar chart in Chart 2 shows that the propensity to vote against board proposals is higher if board directors' judgment of the ability of local laws to empower them is below the mean ( 2.3 versus 1.8 when above the mean). The perception of the quality of local laws therefore cannot explain the high propensity to vote against proposals in Russia, which has the lowest perceived level of director empowering legislation.

In Table 6 we proceed to analyse the relationship between the level of legal empowerment of board directors and their propensity to vote against board proposals. The dependent variable is our indicator of the frequency with which the board director votes against board proposals (1: "Never"; 4: "Often"). All else is as in Table 5. The estimates point to a strongly significant negative correlation between the likelihood of voting against board proposals and board members' judgement on whether local legislation gives them enough power to fulfil their role (while controlling for other director and industry characteristics). Thus, the greater the perceived strength of local legislation, the less a board member feels the need to vote against board proposals. This suggests that board members can function in a less confrontational manner when formal legal institutions provide them with sufficient backing, as the credible threat of a resolution through courts provides important additional power to board members. In contrast, we again find no such role for the more generic question on court quality (columns 3 and 4). When we add both variables at the same time (columns 5 and 6), we continue to find a strong and highly significant negative relationship between director empowerment and active voting behaviour.

We also note that when we include country fixed effects in the even columns we continue to find a strong negative relation between legal empowerment and voting against board proposals (the coefficient actually increases in size). This indicates that within-country variation in (perceived) legal protection is an important determinant of board conduct and not 
just between-country variation. Formal legal protection on the book may not apply in equal measure to all board directors, or may be perceived in different ways, and our findings suggest that those who feel most exposed to a lack of legal back-up are the ones that resort more frequently to active voting. To put it the other way around, those that feel the power of the courts on their side are also those that are most at ease in the boardroom.

\section{Table 6}

Legal empowerment and the voting activity of board directors

\begin{tabular}{|c|c|c|c|c|c|c|}
\hline & \multicolumn{6}{|c|}{ Votes against } \\
\hline & (1) & (2) & (3) & (4) & (5) & (6) \\
\hline \multirow[t]{2}{*}{ Legislation empowers } & $-0.244 * * *$ & $-0.306^{* * * *}$ & & & $-0.191 * *$ & $-0.271 * * *$ \\
\hline & {$[-3.508]$} & {$[-3.553]$} & & & {$[-2.461]$} & {$[-2.721]$} \\
\hline \multirow[t]{2}{*}{ Court quality } & & & $-0.268^{*}$ & -0.217 & -0.155 & -0.126 \\
\hline & & & {$[-1.791]$} & {$[-1.014]$} & {$[-0.995]$} & {$[-0.612]$} \\
\hline \multirow[t]{2}{*}{ Industry experience } & 0.073 & 0.169 & 0.145 & 0.241 & 0.123 & 0.191 \\
\hline & {$[0.524]$} & {$[1.053]$} & {$[0.960]$} & [1.322] & [0.839] & [1.108] \\
\hline \multirow[t]{2}{*}{ Male } & 0.063 & 0.194 & 0.004 & 0.151 & 0.025 & 0.180 \\
\hline & {$[0.378]$} & {$[0.858]$} & [0.021] & {$[0.588]$} & {$[0.133]$} & [0.749] \\
\hline \multirow[t]{2}{*}{ Two-tier board } & -0.192 & -0.247 & -0.119 & -0.168 & -0.129 & -0.157 \\
\hline & {$[-1.159]$} & {$[-1.234]$} & {$[-0.695]$} & {$[-0.803]$} & {$[-0.765]$} & {$[-0.775]$} \\
\hline \multirow[t]{2}{*}{ Finance sector } & $0.417 * * *$ & $0.509 * * *$ & $0.323 * *$ & $0.411 * *$ & $0.368 * *$ & $0.477 * *$ \\
\hline & {$[2.952]$} & [2.904] & [2.103] & [2.127] & [2.431] & {$[2.535]$} \\
\hline Director region fixed effects & No & Yes & No & Yes & No & Yes \\
\hline Country fixed effects & No & Yes & No & Yes & No & Yes \\
\hline Observations & 122 & 122 & 112 & 112 & 112 & 112 \\
\hline R-squared & 0.125 & 0.356 & 0.088 & 0.326 & 0.123 & 0.385 \\
\hline
\end{tabular}

Source: EBRD Board Director Survey.

Note: This table presents linear probability regressions to estimate the relationship between perceived legal empowerment of directors and the voting activity of board directors. Even columns include fixed effects for the director's home region and country fixed effects. Table A1 contains all variable definitions. Robust $\mathrm{t}$-statistics in brackets. $* * * \mathrm{p}<0.01, * * \mathrm{p}<0.05, * \mathrm{p}<0.1$.

We can summarise the evidence in this section as follows. First, in most cases, board directors are active decision-makers, who exercise both advisory and monitoring functions. Second, there is significant heterogeneity across regions in how frequently directors perform these functions. Third, directors are more likely to be actively involved in strategic decisionmaking if they are more confident of the quality of the legal system. Fourth, Russia is unique among regions in that their boards have little say on strategic issues, while directors more frequently vote against board proposals. 


\section{Conclusions}

This paper uses a survey of 130 non-executive board directors in 27 emerging markets to obtain detailed information about the behaviour and conduct of the boards they are part of. We document substantial variation across and within countries in terms of how board directors perceive their own role, the role of their board, and the strength of the legal and institutional environment. Our analysis reveals that the greater the perceived protection of local legislation, the less a board member feels the need to vote against board proposals. This suggests that board members can function in a less confrontational manner when formal legal institutions provide them with sufficient backing. Moreover, our results indicate that if board directors are adequately empowered by local legislation, it is more likely that the boards they comprise play a stronger role in the company's strategic decision-making.

The evidence suggests that boards are active decision-makers, and exercise both advisory and monitoring functions. We also find that board activity becomes intensified in periods of crisis, although information quality does not improve. Finally, we find that Russia is unique among the regions included in our study. Of all regions represented in our sample, Russia has the lowest board quality score, the lowest level of board participation in strategic decisions, and the lowest perceived level of director-empowering legislation. In addition, board independence levels in Russia are quite low. Perhaps as a reflection of the difficulties of working on Russian boards, directors in our sample - who are independent by design - vote against board proposals relatively frequently. 


\section{References}

R.B Adams and D. Ferreira (2007), "A Theory of Friendly Boards", Journal of Finance 62(1): 217-250.

R.B Adams, B.E. Hermalin and M.S. Weisbach (2010), "The Role of Boards of Directors in Corporate Governance: A Conceptual Framework and Survey", Journal of Economic Literature 48(1): 58-107.

T. Beck, H. Degryse, R. De Haas and N. van Horen (2017), "When Arm's Length is Too Far: Relationship Lending over the Business Cycle", Journal of Financial Economics, forthcoming.

B. Black and W. Kim (2012), "The Effect of Board Structure on Firm Value: A Multiple Identification Strategies Approach Using Korean Data", Journal of Financial Economics 104(1): 203-226.

M. Campello, J.R. Graham and C.R. Harvey (2010), "The Real Effects of Financial Constraints: Evidence from a Financial Crisis", Journal of Financial Economics 97: 470-487.

J. Dahya, O. Dimitrov and J.J. McConnell (2008), "Dominant Shareholders, Corporate Boards, and Corporate Value: A Cross-Country Analysis", Journal of Financial Economics 87: 73-100.

T. Eisenberg, S. Sundgren and M.T. Wells (1998), "Larger Board Size and Decreasing Firm Value in Small Firms, Journal of Financial Economics 48(1): 35-54.

D. Ferreira, T. Kirchmaier and D. Metzger (2010), "Boards of Banks", ECGI-Finance Working Paper, European Corporate Governance Institute.

M. Giannetti, G. Liao and X. Yu (2015), "The Brain Gain of Corporate Boards: Evidence from China”, Journal of Finance LXX(4): 1629-1682.

J.R. Graham, C.R. Harvey and M. Puri (2015), "Capital Allocation and Delegation of Decision-Making Authority within Firms", Journal of Financial Economics 115: 449470.

M. Harris and A. Raviv (2008), "A Theory of Board Control and Size”, Review of Financial Studies 21: 1797-1832.

B. Hermalin and M. Weisbach (1998), "Endogenously Chosen Boards of Directors and Their Monitoring of the CEO", American Economic Review 88: 96-118.

Institute of International Finance (IIF) (2002), "Policies for Corporate Governance and Transparency in Emerging Markets”. 
D. Jenter and F. Kanaan (2015), "CEO Turnover and Relative Performance Evaluation", Journal of Finance 70(5): 2155-2184.

R. Leblanc and J. Gillies (2005), Inside the Boardroom. How Boards Really Work and the Coming Revolution in Corporate Governance, John Wiley \& Sons, Ontario.

L.F. Klapper and I. Love (2004), "Corporate Governance, Investor Protection and Performance in Emerging markets", Journal of Corporate Governance 10(5): 703-728.

B.D Nguyen and K. Meisner Nielsen (2010), “The Value of Independent Directors: Evidence from Sudden Deaths", Journal of Financial Economics 98: 550-567.

M. Schwartz-Ziv and M.S. Weisbach (2013), "What Do Boards Really Do? Evidence from Minutes of Board Meetings", Journal of Financial Economics 108: 349-366.

F. Song and A. Thakor (2006), "Information Control, Career Concerns, and Corporate Governance", Journal of Finance 61: 1845-96.

D. Yermack (1996) "Higher Market Valuation of Companies with a Small Board of Directors", Journal of Financial Economics 40(2): 185-211. 


\section{Annex 1: The survey instrument}

\section{Introduction}

Dear [Name],

The aim of this short survey is to learn more about corporate boards in transition countries.

The survey has been sent to all current and past EBRD board nominees. Your answers will deepen our understanding of how boards currently operate, how they react to changes in the firm's environment, and how the functioning of boards differs across countries and across types of boards. We hope that the findings of this survey will help the EBRD to further develop its policies towards improving corporate governance in the transition region.

We would like to stress that your answers will be treated confidentially and will only be used in anonymous format. We can assure you that only the survey team will have access to the data. We greatly appreciate your cooperation and your willingness to share your valuable experience as board members with us. We hope you will be able to respond to this survey by 1 October at the latest. Your support is much appreciated.

Please use the red arrow bars at the bottom of the page to navigate forwards or backwards. You can stop at any time and restart the survey by clicking on the link to the survey in the email.

With best regards,

Erik Berglöf, Chief Economist, EBRD

Ralph De Haas, EBRD

Daniel Ferreira, London School of Economics

Tom Kirchmaier, Manchester Business School \& London School of Economics
About you
1. Are you currently a regular employee of the EBRD?
2. If not, have you been employed by the EBRD in the past?
3. What is your main country of residence?
4. Are you currently still on the board of [company]? 
5. Besides [company], are you currently a member of any other board?

6. On how many boards are you currently a member?

a. Boards of for-profit companies?

b. Board of non-profit organisations?

[number]

7. When did you leave the board of [company]?

[year]

8. Looking back to 2005-10, have you been a member of a board other than [company]'s?

[Please list all companies of which you have been a board member since 2005. Where are they incorporated?]

9. When did you join, and possibly leave those boards?

In the following, all our questions will relate to the board of [company].

10. Does [company] have a one-tier or two-tier board? (Note: A two-tier board is characterised by a separate management and supervisory board.) [One/two-tier board]

11. How many days a month do you spend on average on board duties for [company]?

[Number of days per month]

12. Have you previously worked (not as a board member) in [company]'s industry?

13. For how long have you worked in this industry?

[Number of years]

14. Have you ever had another board appointment in the same industry as [company]? [Y/N]

15. During your tenure on the board of [company], have you ever been (or still are) a member of a board committee? [Y/N]

16. On which board committees of [company] have you served (or are you still serving)?

\begin{tabular}{|l|l|l|l|l|}
\hline & No & Yes & $\begin{array}{c}\text { If yes, as } \\
\text { member }\end{array}$ & $\begin{array}{c}\text { If yes, as } \\
\text { chairperson }\end{array}$ \\
\hline Audit & & & & \\
\hline Nomination & & & & \\
\hline Remuneration & & & & \\
\hline Other & & & & \\
\hline
\end{tabular}


17. Is the chairperson of the Audit committee an independent outside director (i.e. independent from management or dominant owners)? [independent/not independent]

\section{Board structure}

In the following, we are interested to know more about the board structure of [company] at two points in time, namely at the end of 2007 and the end of 2009. Note that for the purpose of this survey we define executive directors as those directors that are managers in the company and receive a salary for their management work. Non-executive directors are "outside" directors who are not actively involved in the daily management of the company.

18. What was the number of executive directors at the end of 2007 ?

19. What was the number of executive directors at the end of 2009 ?

20. What was the number of non-executive directors at the end of 2007 ?

21. What was the number of non-executive directors at the end of 2009 ?

22. How many non-executive directors were foreign at the end of 2007 ?

23. How many non-executive directors were foreign at the end of 2009 ?

24. How many non-executive directors were female at the end of 2007 ?

25. How many non-executive directors were female at the end of 2009 ?

26. What is - approximately - the average age of the non-executive directors on the board of [company] today? [Below 35 / 36-45 / 46-55 / 56-65 / 66 and above]

\section{Board conduct}

27. How many times did the board meet in $2007 / 2009$ ?

[Number each]

28. How long did a typical board meeting last [in hours]?

[Number each]

29. How many days before the board meeting did you typically receive the board papers?

[Number each]

30. Do you think the information that was provided prior to the board meeting in 2007/2009 was: [Far too much / Too much / About right / Too little / Far too little]

31. How many board meetings of [company] did you attend in 2007/2009: 

a. In person
[Number each]
b. By telephone/videoconference
[Number each]
c. Did not participate

32. For a typical board meeting of [company], what percentage of board members participated by telephone in 2007/2009?

33. Does the board hold annual strategy away days?

34. Do all non-executives meet regularly without the management being present?

\section{About the firm}

35. At [company], who usually makes the final decision on strategic issues?
a. Management
b. Board
c. Majority shareholder

36. Was the CEO at the end of 2007 still the CEO at the end of 2009 ?

a. If not, has the board initiated the replacement?

b. If not, had this change been planned in or before 2007 ?

37. At [company], how many non-executive directors have left since 1 January 2008 ? [Number]

38. How good is the board's knowledge of the second level of management (below the board)? [Very bad / Bad / Poor / Fair / Good / Very good]

39. Has [company] raised new funding since September 2008? (Tick all appropriate options) [Equity/ Bank credit / Non-bank long-term debt / Government funding / support]

40. Has [company] suspended paying dividends at any time since September 2008? [Y/N/ has not paid a dividend yet]

41. How involved has the board been in these financial decisions? [Very involved / Involved / Not very involved / Did not discuss] 
42. Please check all the strategic actions [company]'s board has considered for each of the following two time periods (prior and post September 2008): [tick appropriate]

a. Has [company]'s board considered selling the firm?

b. Has the board considered selling parts of its operation?

c. Has [company] sold parts of its operation?

d. Has [company]'s board considered acquiring another firm?

e. Has [company]'s board discussed to more actively pursue an increase in market share?

Has [company]'s board discussed the possibility of entering new markets?

f. Has [company]'s board considered refocusing the activities of the company?

\section{The institutional environment}

43. Does [company] include a corporate governance code as part of its by-laws? [Y/N/don't know]

44. How long is the term for which each board member is elected?

45. Are all board members elected at the same time, or on a rotating basis? [Y/N]

46. In what year did the current chairperson take on that role?

47. At [company], are the CEO and the chairperson the same, or different people?

[Same/different persons]

48. Who typically proposes new board members at [company]? [Rank: current board members/CEO/chairperson/shareholders]

49. Would you agree or disagree that the local legislation of [company]'s country of registration gives you personally enough power to adequately fulfil your role within the board?[Strongly disagree/disagree/somewhat disagree/somewhat agree/agree/strongly agree]

50. To what extent would you say that non-executive directors at [company] are truly independent (i.e. from management or dominant owners)? [Very 
independent/independent/somewhat independent/somewhat dependent/dependent/very dependent]

51. Is the government involved in the nomination process of new directors of [company]? [Yes, formally involved as a shareholder/yes, informally involved/no, not involved/don't know]

\section{The financial crisis}

52. In your own judgment, how has [company] coped with the financial crisis? badly/badly/poorly/fair/well/very well]

53. Overall, how do you judge the performance of [company]'s board during that time? Was it: [Very Ineffective/ineffective/somewhat ineffective/somewhat effective/effective/very effective]

54. In your own opinion, would you say that [company]'s board has made a difference as to how the firm performed during the crisis? [Rank 1-9 (the higher the number, the more impact)]

55. How many times did the board meet between September and December 2008? [Number]

56. Overall, would you say that [company] is now stronger or weaker than in 2007? [Much weaker/weaker/somewhat weaker/somewhat stronger/stronger/much stronger]

57. Looking back at the time of the financial crisis, how would you characterise the discussion in the boardroom of [company]? Would you see it more as antagonistic, or as co-operative? [Very antagonistic/antagonistic/somewhat antagonistic/somewhat cooperative/co-operative/very co-operative]

58. Looking back at the time of the financial crisis, how would you characterise the discussion in the boardroom of [company]? Would you see it more as protracted, or as efficient? [Very protracted/protracted/somewhat protracted/somewhat efficient/efficient/very efficient]

59. Looking back at the time of the financial crisis, how would you characterise the discussion in the boardroom of [company]? Would you see it more dominated by a few, or inclusive and democratic? [Very much dominated by a few/dominated by a 
few/somewhat dominated by a few/somewhat inclusive and democratic/inclusive and democratic/very inclusive and democratic]

60. How would you judge the competence and qualification level of the CEO and the board as a whole? [For each: Very competent and qualified/competent and qualified/somewhat competent and qualified/somewhat incompetent and under-qualified/incompetent and unqualified/very incompetent and unqualified]

\section{Case}

In the following we would like to present you with a short case. Buyer Co. ("Buyer') is a food manufacturer. It is a publicly traded firm listed on your largest stock exchange. Mr. James is Buyer's controlling shareholder and a member of its board of directors. He owns 60 per cent of Buyer, and elected two more directors to Buyer's five-member board of directors. Buyer's CEO is the son of Mr. James. Mr. James also owns 90 per cent of Seller Co., which operates a chain of retail hardware stores. Seller recently shut down a large number of its stores. As a result, its fleet of trucks is not being utilised.

Mr. James proposes that Buyer purchase Seller's unused fleet of trucks to expand Buyer's distribution of its food products. The final terms of the transaction require Buyer to pay to Seller in cash. The transaction is part of Buyer's ordinary course of business.

Buyer enters into the transaction. All required approvals are obtained and all the required disclosures made. The transaction might be unfair to Buyer. Shareholders sue the interested parties and Buyer's board.

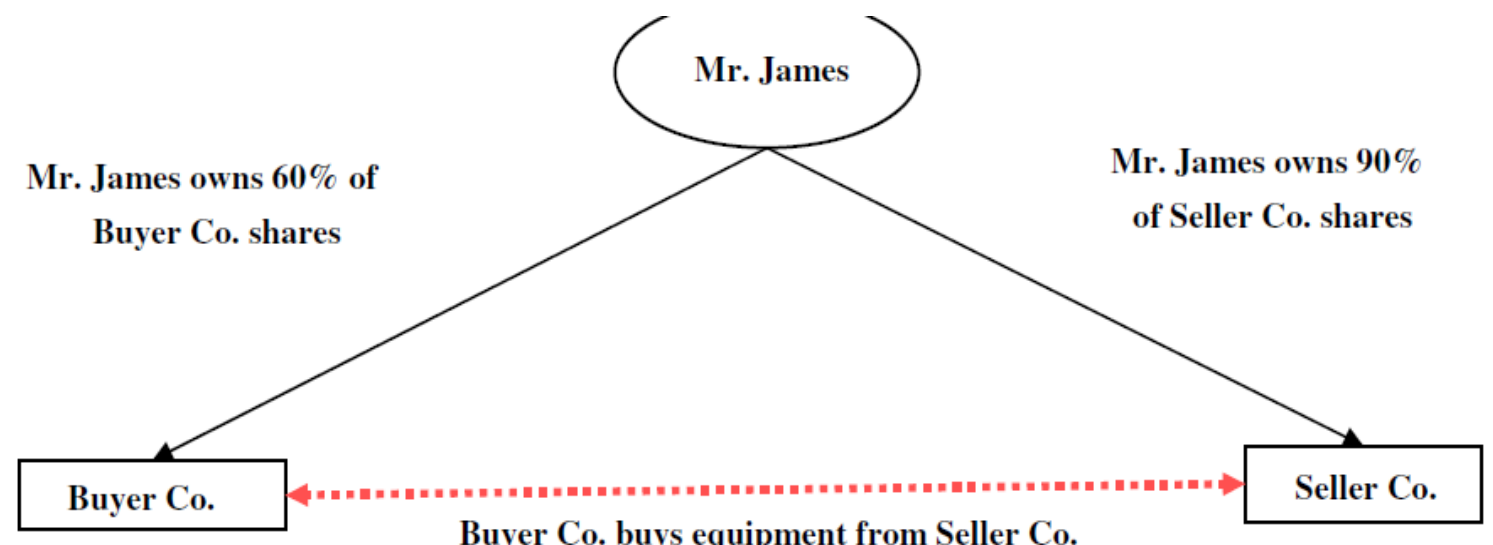

61. Do you think the court will decide in favour of the board, or the shareholders? [board/shareholders] 
62. In general, do you think the courts would rule fairly and objectively? [y/n]

63. Are there any other comments/clarifications you might have? 
Annex 2

Table A1

Variable definitions

\begin{tabular}{|c|c|}
\hline \multicolumn{2}{|l|}{ Director characteristics } \\
\hline Male & Dummy $=1$ if director gender is male; 0 if female \\
\hline Western & Dummy $=1$ if director nationality is Western European or North American; 0 otherwise \\
\hline Board experience & Dummy $=1$ if director has previously been a board member at another company; 0 otherwise \\
\hline Industry experience & Dummy $=1$ if director has previously worked in the sector of the current company; 0 otherwise \\
\hline \multicolumn{2}{|l|}{ Company characteristics } \\
\hline Finance sector & Dummy $=1$ if comp any is in the financial sector; 0 otherwise \\
\hline Two-tier board & Dummy $=1$ if company has a two-tier board, i.e. a separate management and supervisory board; 0 otherwise \\
\hline Board size & Number of directors on the board \\
\hline Female participation & Share of female directors on the board \\
\hline Minority independent board members & Dummy $=1$ if independent board directors hold less than half of all board seats; 0 \\
\hline NED share & Share of non-executive directors on the board \\
\hline \multicolumn{2}{|l|}{ Board conduct and meeting characteristics } \\
\hline Board duties & Number of days per month the director spends on average on board duties \\
\hline Board sets clear targets & Dummy $=1$ if director thinks that the board clearly defines financial and operational targets for senior management; 0 otherwise \\
\hline Board follows up on targets & Dummy $=1$ if the board systematically follows up on financial and operational targets set for senior management; 0 otherwise \\
\hline Meets without management & Dummy $=1$ if the non-executive directors meet at least once a year without the management being present; 0 otherwise \\
\hline Strategy-away days & Dummy $=1$ if board holds strategy-away days (dedicated discussion meetings in a location away from the office); 0 otherwise \\
\hline Knowledge of management & Opinion of director on the board's knowledge of the second level of management (below the board) (1: very bad; 6 : very good) \\
\hline Competence \& qualification of board & Dummy $=1$ if director thinks the board is very qualified; 0 otherwise \\
\hline Board quality index & Unweighted average of five normalised variables: Strategy away days; Meets without management $;$ Board sets clear targets $;$ Board follows up on targets; and Competence \& qualification of board \\
\hline Meeting quality index & Unweighted average of four normalised variables: Number of board meetings (per year); Duration board meeting; Percentage by telephone; and Days before board papers received \\
\hline Meeting intensity index & Unweighted average of three normalised variables: Number of board meetings (per year); Duration board meeting ; and Percentage by telephone \\
\hline Meeting information index & Unweighted average if two normalised variables: Sufficient information and Days before board papers received \\
\hline Number of board meetings & Number of board meetings per year \\
\hline Duration board meeting & Duration of a typical board meeting in hours \\
\hline Percentage by phone & Percentage of board directors that typically participates in board meetings via a telephone connection \\
\hline Sufficient information & Dummy $=1$ if director thinks the quantity of information they receive prior to a board meeting is about right; 0 otherwise \\
\hline Days before board papers received & Number of days before the board meeting that the director typically receives the board papers \\
\hline \multicolumn{2}{|l|}{ Power distribution within the board } \\
\hline Chairperson sets board agenda & Dummy $=1$ if the chairperson of the board typically determines the board agenda; 0 otherwise \\
\hline Final decision with board & Dummy $=1$ if final decisions on strategic issues are usually taken by the board; 0 if these decisions are usually taken by management or the majority shareholder \\
\hline Votes against & Frequency with which the director votes against board proposals (1: never; 4 : often) \\
\hline Never votes against & Dummy $=1$ if the board member never votes against board proposals; 0 otherwise \\
\hline \multicolumn{2}{|c|}{ Board director views on judicial fairness and empowerment } \\
\hline Court quality & Dummy $=1$ if director thinks that the local court would rule fairly and objectively in a given case; 0 otherwise \\
\hline Legislation empowers & Opinion of director on whether local legislation gives her enough power to adequately fulfil her role within the board (1: strongly disagree; 6 : strongly agree) \\
\hline No role government nominating new directors & Dummy $=1$ if director thinks that the government is typically not involved in the nomination process of new directors; 0 otherwise \\
\hline
\end{tabular}

Source: EBRD Board Director Survey.

Note: This table presents the definitions of all the variables used in the paper. NED=Non-executive director. 